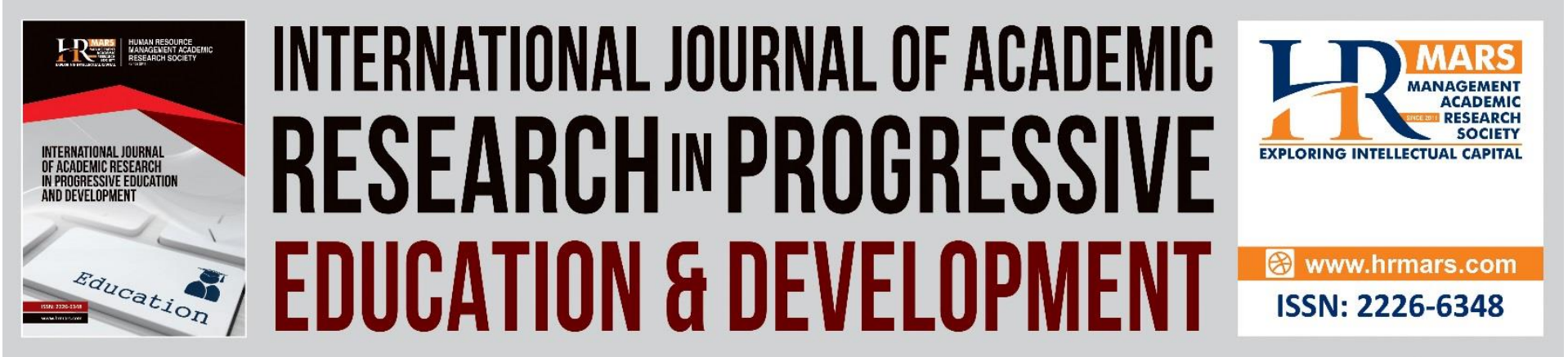

\title{
Legitimacy and Methods of Judicial Review in Islamic Law and Libyan Positive Law
}

Salim Mohamed Ameer Amhalhal, Engku Muhammad Tajuddin B. Eng. Ali

To Link this Article: http://dx.doi.org/10.6007/IJARPED/v10-i3/11633

DOI:10.6007/IJARPED/v10-i3/11633

Received: 20 July 2021, Revised: 24 August 2021, Accepted: 01 September 2021

Published Online: 27 September 2021

In-Text Citation: (Amhalhal \& Ali, 2021)

To Cite this Article: Amhalhal, S. M. A., \& Ali, E. M. T. B. E. (2021). Legitimacy and Methods of Judicial Review in Islamic Law and Libyan Positive Law. International Journal of Academic Research in Progressive Education and Development, 10(3), 1287-1301.

Copyright: (C) 2021 The Author(s)

Published by Human Resource Management Academic Research Society (www.hrmars.com)

This article is published under the Creative Commons Attribution (CC BY 4.0) license. Anyone may reproduce, distribute, translate and create derivative works of this article (for both commercial and non-commercial purposes), subject to full attribution to the original publication and authors. The full terms of this license may be seen

at: http://creativecommons.org/licences/by/4.0/legalcode

Vol. 10(3) 2021, Pg. 1287 - 1301

http://hrmars.com/index.php/pages/detail/IJARPED

JOURNAL HOMEPAGE

Full Terms \& Conditions of access and use can be found at http://hrmars.com/index.php/pages/detail/publication-ethics 


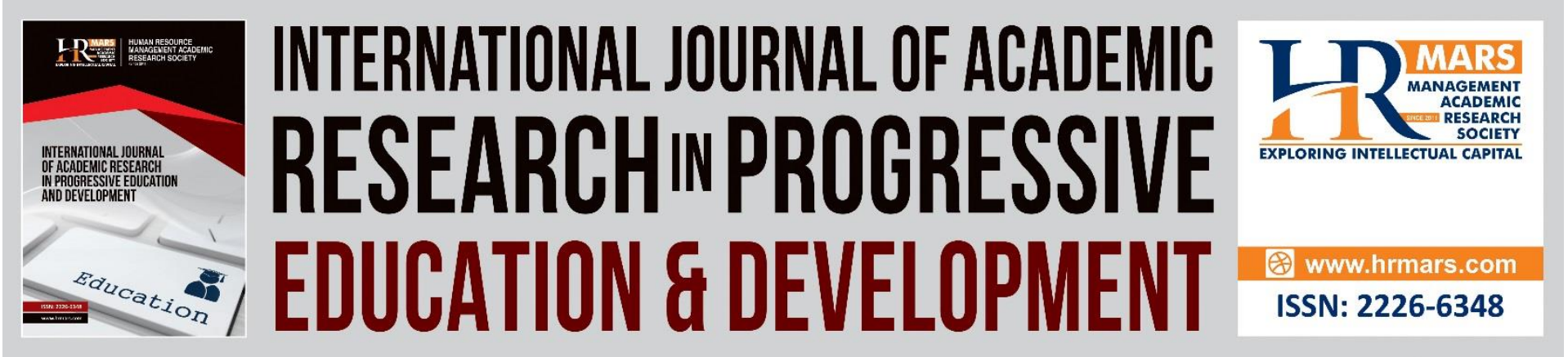

\title{
Legitimacy and Methods of Judicial Review in Islamic Law and Libyan Positive Law
}

\section{Salim Mohamed Ameer Amhalhal, Engku Muhammad Tajuddin B. Eng. Ali}

Faculty of Contemporary Islamic Studies, Universiti Sultan Zainal Abidin, Malaysia.

Corresponding Author: salem15.mohammed@gmail.com

\begin{abstract}
One who observes Islamic law in its entirety will not understand the legitimacy of an action unless he understands its legislative basis. The same can be said for positive law. Therefore, one who looks into the law of a given matter must have the capability to visualize it. This is what motivates us to study the root of the issue of the principle of criminalization to litigation and sentencing and enforcement in order to clarify the wisdom underlying the legitimacy of judicial review. Herein lies the research problem. This study aims to present a clear view about the basis and methods of judicial review in Islamic law and Libyan positive law, as well as explaining the entities responsible for judicial review in Islamic law and Libyan positive law. This study employed the inductive approach and the analytical descriptive method. Every issue related to the study was scrutinized and compiled from various references of Islamic law and Libyan positive law to form the basis of the study. The data were analyzed to sufficiently answer the research problem. The study found important conclusions and recommendations, among them: the legitimacy of judicial review in Islamic law and positive law comes back to the fundamental reasons prohibiting crime. The constitutional basis of judicial review is the constitutional recognition of the right to litigation and legal recourse, as well as the implementation of the two-level litigation principle. This is the approach taken by the Libyan Constitutional Declaration.
\end{abstract}

Keywords: Legitimacy, Review, Judicial Judgment, Islamic Law, Libyan Positive Law.

\section{Introduction}

The fundamental principle of Islamic law is that an individual may not commit an act that can injure himself or another, and that injuring another is proscribed by law. One of the main obligations in Islam is the preservation of human life, in line with the agreed upon principles of Islamic law to proscribe harm and injuring another. Therefore, the most important characteristic of Islamic law in the field of judiciary is not only granting and determining the right to litigate and seek legal recourse in its traditional or contemporary form, but it also prevents the causes of legal recourse, such as civil disputes, misappropriation of wealth, and criminal offences. The final item is the focus of our study. Islamic law fundamentally seeks to prevent crime; this is derived from its lofty rules and principles. 
Therefore, the convicted defendant may appeal for a review to the judge or court, submitting with it evidence of his innocence, if any, or other evidence that can reduce his sentence. In positive law, this is known as judicial review (muraja'ah al-ahkam al-qada'iyyah). It is the steps that follow the legitimacy to appeal against judicial judgments in the outset, hence there is no review for a judgment that can be appealed through legally defined ordinary and extraordinary ways of appeal.

This study will discuss the legal basis of judicial review and clarify the methods of judicial review in legally defined cases of appeal or in the presence of material errors or errors in the law or its mentioning texts according to Islamic law and Libyan positive law. The study comprises three sections as follows.

\section{Definition of Judicial Review}

Review (al-muraja'ah) is etymologically derived from raja'a-yarji u - raj'an - ruju'an. Al-muraja'ah means to return to (al-mu'awadah) (Ibn Manz̧ur, 1994). To review a statement (raja'ahu al-kalam) means to return to it ('awadahu) (al-Fayruz Abadi, 1371).

Al-Muraja'ah in Shariah nomenclature means to return to a matter to begin anew. Among its use is muraja'ah al-qadiyyah (case review), which means re-examining a case (Qal'aji \& Qannabi, 1405). Combining the etymological and terminological definitions, almuraja'ah means the re-examination of a matter that has been decided upon ('Aymur, 2004/2005).

Al-Muraja'ah in legal nomenclature is a request submitted by a person of capacity and interest to a judicial body to challenge an enforced decision or a court order for the purpose of annulling or overturning it (Jarjis, 1996).

Judicial review in positive law differs from that in Islamic law and by types of judgment. Trial judgments issued in absentia may be reviewed by appeal by way of challenging them before the issuing court. Trial judgments issued in person may be reviewed by appeal by filing an appeal to the Court of Second Instance. Final judgments may be reviewed by way of two extraordinary methods of appeal: cassation and rehearing. Final peremptory judgments, which have exhausted all avenues of appeal and judicial review, become res judicata by law. The court or judge that has issued his judgment cannot vacate it or make a new decision on the case. The judge, upon the issuance of final preemptory judgments, has exhausted his jurisdiction over the case, and as such he no longer has the judicial or legal authority to amend his judgment. On the other hand, in Islamic law, the judge may return to and reconsider a judgment that he has issued if it violates the provisions of Islamic law-i.e., by contradicting the Quran, Sunnah, or consensus (ijma ) - or if there emerges a doubt that averts hudud (fixed punishments for certain criminal offences). The judge reviews the case anew and shall not be inhibited by his previous judgment of the case. The difference between Islamic law and positive law in this issue lies in the theoretical and practical methodologies founding the existence of the judiciary in Islamic law. Islamic law relies on the divine method for legislation and judiciary, and it seeks to realize and apply God's law on an incident for preventative, remedial, punitive, and enforcement purposes. These distinguish it from positive law, which looks into the matter from a material perspective founded on legally defined purposes of punishment-strictly remedial, through deterrence, and to achieve justice. On the other hand, the noble divine law looks further to eliminate the need for punishment by removing vices and crimes from society. Islamic judiciary is consistent with Islamic criminal legislation; they are an integrated unit of complementary legislations that can identify and correct errors 
and review judgments of the same judge who issued them in most cases. The judge who issues the judgment is qualified, trustworthy, and capable to perform his duties. Meanwhile, in positive law, the procedural systems require a judge from a court of higher instance to examine a judgment issued by a trial court upon its appeal. In other words, the case is referred to another judge who then examines the judgment. Nonetheless, in some legally defined cases, the judge can examine, review, and amend a judgment that he has issued ('Umar, n.d.).

From the above discussion on positive legislation and Islamic jurisprudence, we find that the legislator of each, in their own way, envisages the interests of society and the defendant. The principal objective of Islamic and positive judicial legislation is always to confront crime and establish security in society with their respective methods and goals. There have been combined efforts from all parts of society, past and present, to prevent crime and inhibit criminals. The incidence of crime in a society does not indicate its elimination of opportunities for the criminals to commit whatever acts-deemed as crimes by the legislator of that society - that they desire. It is just that the inhibition of criminals differs by time and location. Islamic law is the earliest legislation to establish legislative political systems that prevent the incidence of crimes and violation of dignities.

The adjudication policy of Islamic law is demonstrated in its role to prevent crime before deterring it. The judiciary seeks to eliminate crime before punishing the criminal. Thus, it holds the power to impose precautionary (preventative) measures on criminals and outlaws for whom the punishments are absent from the law, and who may appeal against a judgment due to a barrier to impose punishments, such that a judge in the Supreme Court must overturn the judgment upon his review of it. Therefore, precautionary measures are useful in those instances, as it protects society from the threat of the criminal and his crimes in the future, thus establishing security. It is also correct, therefore, to describe them as security measures that can establish security in society (Abu 'Amir \& al-Șayfi, 1997).

Thus, the main purpose of taking necessary measures to reduce the crime phenomena is the protection of society from the dangers of such crimes-which may ensue if such measures are not taken-by establishing the forerunners of danger.

When a court issues an order for a punishment or precautionary measures for a given crime, the defendant reserves the right to appeal against the judgment issued against him, as we have previously discussed. We have also explained judicial judgments that are subject to appeal in Islamic law and Libyan positive law. Judicial review refers to the necessity to review a judgment by a judge. In the following pages, we explain the intent of the legislator behind those appeals and their permissibility, as well as their inclusion of review as one of the duties of the judge based on the right to appeal against judicial judgments. We explain in the following the legal basis for judicial review in Islamic law and Libyan positive law.

\section{Legitimacy of Judicial Review in Islamic Law and Libyan Positive Law Legitimacy of Judicial Review in Islamic Law}

One who observes the general provisions of the noble Shariah will find its profound doctrine of criminal and judicial legislation. The doctrine incorporates the protection and fight against crime and envisages prohibition in implementing punishments, which goes back to the objectives envisaged by the Islamic legislator behind the implementation of punishments. The texts ordering and regulating criminalization and punishments in Islamic law are specific and finite, as there is no revelation after the Apostle of Allah (pbuh). Therefore, every new crime and punishment emerging after the period of revelation must be decided based on the 
legal policy agreed upon by jurists and scholars of the ummah. Upon scrutinizing Shariah evidence, the legitimacy of judicial review in Islamic law becomes clear. This is further detailed below.

\section{First: Evidence for the Legitimacy of Judicial Review in the Noble Quran}

Allah says, "And [remember] when Dawud and Sulayman passed judgment regarding the crops ruined [at night] by someone's sheep, and We were witness to their judgments" (alAnbiya', 21: 78). Imam al-Qurțubi interprets this verse as follows, "His Word: 'And [remember] when David and Solomon passed judgment', that is, remember them when they passed judgment. The phrase 'passed judgment' does not mean the combined judgments of Dawud and Sulayman on the case, even though they are mentioned at the same time. There cannot be two judgments on a single case; instead, each of them passed judgment separately. Sulayman understood the case well as Allah had made him capable to understand. 'Regarding the crops [al-harth]': there are two opinions of the meaning of al-harth. Qatadah said that it refers to a plantation, while Ibn Mas'ud and Shuray said it was a vineyard with dangling clusters of grapes. Al-harth is used for both, but it is beyond metaphor for a plantation. 'Ruined [at night] by someone's sheep' means that the sheep pastured the vineyards at night (al-nafash means to graze at night). 'And We were witness to their judgments': evidence that the minimum quantity for a plural is two. Some said that it refers to the two judges and the subject of judgment, hence 'their judgments'.

"His Word, 'And We made Sulayman to understand [the case],' means that We made him understand the case and adjudication. Both were not directly mentioned as they were previously indicated to. Sulayman's judgment was favored over his father's because he made sure that each party retained their possessions, and as such he kept himself good. Dawud (pbuh) ruled that the sheep should be surrendered to the vineyard owner. When the two disputing parties exited before Sulayman, who was sitting by the door from which they exited (they had entered to meet Dawud from another door), he asked, 'What judgment did the Prophet of Allah Dawud passed for both of you?' They replied, 'He decided that the sheep should be surrendered to the vineyard owner.' Sulayman said, 'The judgment should not be this. Come with me.' He then met his father and asked, 'O Prophet of Allah, you decided like this and that, but I have a judgment that suits everyone better.' Dawud asked, 'What is it?' Sulayman said, 'You should give the sheep to the vineyard owner so that he can benefit from its milk, fat, and wool. Give the vineyard to the sheep owner so that he may tend it. Then, next year, when it returns to the state before the sheep grazed it, they should return their possessions to each other.' Dawud said, 'You have been guided, my son. Allah has not curtailed your understanding.' He then ruled according to Sulayman's judgment. Ibn Mas'ud, Mujahid, and others have paraphrased this narration" (al-Qurțubi, n.d.). The verse and its interpretation evince the permissibility for a ruler or judge to reconsider a judgment that he bases on his own ijtihad (deduction) if there is a stronger ijtihad. This way, truth and justice can be achieved.

\section{Second: Evidence for the Legitimacy of Judicial Review from the Prophetic Sunnah}

Judiciary is the means to execute and implement the laws of Allah the Exalted. The judge rests his judgment on the Book of Allah. If he does not find any reference therein, he shall refer to the Sunnah of the Apostle of Allah (pbuh). It was narrated from the companions of Mu'adh ibn Jabal from among the people of Homs, that when the Apostle of Allah (pbuh) 
intended to send Mu'adh to Yemen, he said, "How will you judge when the occasion to decide a case arises?" Mu'adh answered, "I shall judge in accordance with the Book of Allah." He asked, "What will you do if you do not find any guidance in Allah's Book?" He replied, "I shall act in accordance with the Sunnah of the Apostle of Allah (pbuh)." He asked, "(What will you do) if you do not find any guidance in the Sunnah of the Apostle of Allah (pbuh) and in Allah's Book?" He replied, "I shall do my best to form an opinion and I shall spare no effort." The Apostle of Allah (pbuh) then patted him on the breast and said, "Praise be to Allah Who has helped the messenger of the Messenger of Allah to find something which pleases the Messenger of Allah."

If the adjudication of a judge contradicts the Quran or Sunnah, the judgment becomes invalid. It was narrated that the Mother of the Believers, 'A'isyah (ra.) said, "The Apostle of Allah (pbuh) said, 'He who innovates something in this matter of ours (i.e., Islam) that is not of it will have it rejected (by Allah)'" (al-Bukhari, 1423). This means that such an innovation is invalid; it cannot be invoked and found an argument. It follows from this hadith that a judgment that contradicts the Quran, Sunnah, consensus, apparent analogy (qiyas jali), or general principles must be overturned (al-Shafi $i, 1990)$.

\section{Third: Evidence for Judicial Review from Consensus (ljma')}

Jurists have unanimously agreed on the invalidity of unjust judgment (Ibn Farhun, 2002), and that it must be annulled in accordance with the provisions of Islamic law. This may be carried out by the judge who issued the judgment himself upon his discovery of the error. Judges have withdrawn their judgments if they are unjust. The annulation of a judgment is compulsory if the judge clearly discovers that it contradicts the agreed upon Shariah evidence or is far from truth, justice, and correctness (Radiyah 'Aymur, 2004-2005, 36). It is therefore clear to us the most important evidence for judicial review in Islamic law. The justification for judicial review is the contradiction of judicial judgments with the Quran, Sunnah, consensus, apparent analogy, or general principles, or the presence of error and injustice in the judgment. In this case, the judge himself or a judge from a court of higher instance must annul the judgment. We will explain this during our discussion of judicial review methods in Islamic law.

\section{Legitimacy of Judicial Review in Libyan Positive Law}

The Libyan legislator has recognized in criminal legislation the right to appeal against judicial judgments through ordinary and extraordinary means. Judgments in absentia may be examined by the issuing court upon its challenge by the defendant, while judgments in person may be examined by a court of higher instance by way of appeal, cassation, and rehearing. Therefore, the principle of two-level litigation is achieved in Libyan positive law. The principle aims to provide the opportunity for the court of higher instance to examine the appealed judgment and to grant the defendant the right to be reassured of a judgment that seeks to achieve justice. In positive law, this right is founded on the methodology adopted by the legislator, which achieves justice from the offender without revenge or abuse and serves as a means to confront crime. It stresses that society will not release its right from the offender and that the judiciary will implement the law with integrity and impartiality. Appeal against and review of a judgment only serve to balance the right of the accused to defend himself, utilizing his legally established right to appeal a judgment issued against him, and the right of society to implement justice. It is not justified to say that the objectives of Islamic law in 
dealing with criminalization, punishment, and criminal justice differ from those of positive law, and that the positive law only considers material matters. Indeed, it is similar to Islamic law in that it is firstly a preventative law which seeks to sever and prevent crime, preserving the rights of human regarding his humanity while deterring him from committing crime. Undoubtedly, the most important goal of punishment in any criminal legislation is to deter the criminal. This deterrence appears as a remedy for the threat inherent in the personality of the criminal and can remove this threat from himself, so that he will not repeat his crimes and think about committing them. No legislation imposes punishment for the purpose of curing, taking revenge on, or calibrate the offender. The purpose of punishment is always to reform and remedy, thus allowing the offender to lead a decent, upright life in society and mix with its members without frightening them and earn their disapproval. The offender only commits a crime because of a dysfunction within himself that pushes him to tread the path of crime and permits himself to commit such an act. It is primarily a psychological matter, though there are also social factors that contribute to crimes, such as economic factors, urbanization, industrialization, and education (al-Hasan, 2001).

The political, social, economic, and administrative conditions experienced by Libya have prevented its judiciary from keeping pace with legal developments and judicial judgments at the regional and global levels. Many diseases began to corrode the justice system and reduce the significant efforts made thus far. Perhaps the most significant of them are the accumulation of files, slow decision-making on cases, ineffectiveness of certain procedures, and intimidations faced by some judges. These have made the Libyan society, like most Arab societies, in dire need of protection from crime from the outset, so that it does not reach the judiciary, appeal, judicial review, imposition or elusion of punishment, and other issues currently faced by the Libyan legislator ('Awdah, 2019). Judicial review and the implementation of appeal methods can perhaps result in more justice and better prevention of crime by way of intimidation and deterrence. They can realize multiple benefits, the most important of which is alleviating the burden of the judiciary during a difficult time in the history of the Arab world in general and Libya in particular.

To discuss the legal basis for judicial review in Libyan positive law, we must explain its constitutional and legal bases. These are discussed as follows.

\section{First: Constitutional Basis for Judicial Review in Libyan Positive Law}

The constitutional basis for judicial review is the constitutional recognition of the right to litigation and legal recourse and the implementation of the two-level litigation principle. The Libyan constitution is not a novel legislation. Article 31 of the Libyan Constitutional Declaration of 2011 and its Amendments declare that "every citizen shall have the right to have recourse to the judiciary in accordance with the law" (Libya, 2011).

\section{Second: Legal Basis for Judicial Review in Libyan Positive Law}

Scrutinizing judicial and criminal legislation texts, we find that that they clearly recognize the two-level litigation principle, the right to litigate and appeal, and the judicial review doctrine. Thus, it is necessary to explain the levels of litigation for criminal cases and their issues. These are discussed below. 
DEVELOPMENT

Vol. 10, No. 3, 2021, E-ISSN: 2226-6348 ㄷ 2021 HRMARS

1. First Level of Criminal Case Adjudication in Libyan Positive Law

Summary Courts are the courts of first instance for misdemeanors, infractions, and specific cases of felonies, i.e., if the felony is accompanied by a legal excuse or extenuating circumstance that would reduce the penalty to the level of a misdemeanor. Article 188 of the Libyan Code of Criminal Procedure states, "The Summary Court shall preside over every action deemed by law as an infraction or misdemeanor. It shall also preside over felonies referred to it by the investigative magistrate or Indictment Chamber, in accordance with Articles 136 and 153, or those which it decides to examine, in accordance with Article 279." (Libya, n.d.).

2. Second Level of Criminal Case Adjudication in Libyan Positive Law

The second level of litigation is carried out by a higher judicial body responsible for judicial review. A court of higher degree examines the issued judgment to affirm, annul, or amend it such that justice and correctness can be achieved.

The second level is the court to which appeals against criminal judgments are filed. The Libyan legislator has permitted appeal against judgments issued by the Summary Court on criminal cases in misdemeanors and infractions. Article 365 of the Libyan Code of Criminal Procedure states, "Judgments issued by the Summary Court on criminal cases in infractions and misdemeanors may be appealed:

a. By the defendant if he is sentenced to other than a fine and expenses or a fine exceeding five dinars.

b. By the Public Prosecution if it has demanded a sentence other than fines and expenses or a fine exceeding five dinars, and the defendant has been acquitted or the sentence imposed does not satisfy the Public Prosecution's demand. Excepting the above cases, neither the defendant nor Public Prosecution can file an appeal, except in the case of an error in the implementation or interpretation of legal texts" (Libya, n.d.).

\section{Methods of Judicial Review in Islamic Law and Libyan Positive Law}

The concept of judicial review in Islamic law and positive law is founded on the legislative philosophy of judicial judgment. In Islamic law, this means the interest of the individual and the ummah; in positive law, it is the three objectives of criminalization and punishment. The methods, mechanisms, and procedures of judicial review in Islamic law differ from those in positive law. Nonetheless, they are fundamentally similar. These are explained further below.

\section{Methods of Judicial Review in Islamic Law}

The legal basis of judicial review from the Quran, Sunnah, and consensus has been explained above. The researcher shall discuss the methods of judicial review in Islamic law by clarifying its mechanism and the responsible entity. These are presented below.

\section{Judicial Review Mechanism in Islamic Law}

As discussed above, scholars have unanimously agreed that a judicial judgment is void if it contradicts the texts of Shariah or contains an error or injustice. However, jurists hold at least three views on the mechanism to review and overturn a judicial judgment.

The first view is that a judge cannot overturn a judgment that he has personally issued. Instead, he corrects his opinion in subsequent judgments without prejudice to past 
judgments. 'Umar bin al-Khațțab (ra.) in his advice to Abu Musa al-Ash'ari (ra.), as mentioned previously, said, "It is permissible for you to reconsider a judgment that you passed yesterday after you have received guidance on that matter. The truth is constant, and [your] reconsideration to achieve the truth is better than persisting in untruth" (al-Bayhaqi, n.d.).

Ibn Qayyim al-Jawziyyah in his interpretation of this statement says, "The first judgment does not prevent him from reconsidering the second, and the second judgment cannot overturn the first. The imams of Islam after him have held on to these two principles" (Ibn Qayyim al-Jawziyyah, 1991). It is clear, then, according to scholars holding the first view, that there are two foundations or principles for judicial judgments ('Allam, 2012):

a. the judgment is fixed and should not be returned to;

b. if the judge discovers an error in a judgment that he has issued, then he must avoid this error in subsequent judgments. It was narrated from 'Umar ibn al-Khațțab that he once made a certain judgment on an incident, but he then passed a different judgment on a similar incident. He was asked about that, and so he explained, "That was how we used to judge, and this is how we judge now" (al-Kasani, 1987).

The second view is that if a judge discovers an error in his judgment, then he must immediately overturn and vacate it. This is the opinion of 'Umar ibn 'Abd al-'Aziz. Yahya ibn Sa'id and Rabi'ah ibn Abi 'Abd al-Rahmman said, "'Umar ibn 'Abd al-'Aziz said, 'No clay is easier for me to loosen; and no book is easier for me to rebut than a book with which I judge, after which I found the truth residing in another, and so I annul it" (al-Bayhaqi, n.d.).

The third view is that a judge cannot return to his judgment except if he discovers an error that contradicts the Quran, Sunnah, or consensus. He may not return to a judgment made based on his ijtihad. Imam al-Sarakhsi of the Hanafi school said, "If a judge passes a judgment, and then it becomes evident to him that he should retract it: if the error in judgment relates to something that is not disputed upon, then he should retract and annul it. This is, if the judgment contradicts the nașș [i.e., Quran and Sunnah] and consensus. A judgment that contradicts the naș and consensus is invalid and is an oversight on the part of the judge. A hadith states, 'Return whatever is unknown to the Sunnah.' If the error relates to a matter that is disputed upon, then the judge should leave the judgment as is, and he should judge subsequent cases based on what his ijtihad arrives to and what he perceives to be the best. This is because the judgment falls in the jurisdiction of ijtihad, hence it becomes effective and necessary, such that it cannot be annulled. This is based on a narration, that 'Umar (ra.) issued a certain judgment for an incident, but he made another judgment when a similar case was presented before him. When he was asked about it, he said, 'That was how we used to judge, and this is how we judge now.' Al-Sha 'bi (ra.) said, 'I memorized 70 hudud cases from 'Umar (ra.), each different from the other.' It is clear, therefore, that an ijtihad cannot be overturned by a similar ijtihad. Instead, the judge issues his judgment in subsequent cases based on what his ijtihad arrives to. This is based on the investigation of qibla direction. It was narrated that Shurayh (ra.) once issued a judgment, whose error then became apparent, and so he reconsidered it. But he did not return to judgments made based on his ijtihad. If he changed his mind, he would base his judgment on future cases according to what his ijtihad led him, and he did not overturn his previous judgments" (al-Sarakhsi, 1993).

Sheikh Khalil al-Maliki explained in his Mukhtașar, "The judgment of an unjust judge, or an ignorant judge who has not deliberated [his judgment] with scholars, should be rejected. But if the ignorant judge does deliberate with scholars, [then his judgments should not be 
outright rejected, but] they should be re-examined [for the purpose of review]. The judgment of a judge who is not unjust should be left as is. The judgment of a just, learned judge should not be re-examined. It can be overturned by the judge himself or another judge, but he should explain the reason for such, be it contravention to definitive evidence [i.e., definitive parts of the Quran, Sunnah, or consensus] or apparent analogy. The judge may overturn his own judgment if he sees that another judgment is more correct or the judgment is outside of [the scope of] his own opinion [e.g., due to oversight] or the opinion of his imam" ('llish, 1989).

\section{Second: Judicial Review Entity in Islamic Law}

Muslim jurists unanimously agree that in principle, the judgment issued by a judge is conclusive and binding for both parties. Nonetheless, they allow judicial review and appeal due to the possibility of an error in the judgment, since the judge is but a human (Wașil, n.d., 259), and since error itself is indicated to in a hadith narrated by 'Amr ibn al-'As (ra.), that he heard the Apostle of Allah (pbuh) said, "If a judge makes a correct judgment, he shall earn two rewards; if he makes an incorrect judgment, he shall receive a single reward" (al-Bukhari, 1423). The review and overturn of a judicial judgment by the judge himself is the achievement of truth, affirmation of justice, and acknowledgment of the judge's duties as sanctioned by Islamic law. The judge is the first and last person responsible for the judgment and its content in this world and the hereafter.

It is clear from the above that a judicial judgment may be reviewed before a higher entity, such as the chief justice, ombudsman, or caliph and guardian per se. This provides more guarantee that the judgment is indeed closer to the truth and correctness and is consistent with the noble law of Allah.

If the judicial system is based on a single-judge system: there is no legal barrier against the appointment of more than a single judge, where the court may comprise three or more judges. Islamic law seeks to realize truth and achieve justice, and the presence of more than a single judge will result in a more accurate judgment and significantly reduce the error rate, thereby ensuring the validity of judicial judgments ('Aymur, 2004-2005).

The Libyan legislator has permitted appeal against provisions of hudud punishments before the supreme court. Article 16 of Law No. 13/1425 AD on the Establishment of Hudud for Theft and Hirabah (banditry/brigandage/robbery) states, "Excepting the established principles and procedures for appeal by cassation against final judgments, if the judgment issued in person calls for hudud punishment in the two offences specified in Articles 1 and 4 of this Law, the case and its records must be presented before the Supreme Court within forty days of the judgment. The court shall appoint an attorney for the defendant if he is without one. The Public Prosecution shall submit a motion containing its opinion within fifteen days after the presentation, while the defense attorney shall submit his defense only within the other fifteen days." (Libya, 1425).

As the above Article shows, the Libyan legislator clearly specifies that the judgments issued on the two hudud offences of theft and hirabah are reviewed by the Supreme Court within 40 days of the date of their pronouncement. This is due to the necessity of judicial review for theft and hirabah, which are considered as among the worst offences with severe punishments, thus justifying the legality to appeal against and review their judgments and the opportunity to overturn or amend them.

The Libyan legislator has stressed the necessity of review for judgments related to theft and hirabah, as it requires suspending the enforcement of such judgments until the Supreme 
Court completes its adjudication of the case. Article 17 of Law No. 13/1425 AD on the Establishment of Hudud for Theft and Hirabah states, "The judgment to impose hudud punishment shall not be enforced until the Supreme Court completes its adjudication of the case" (Libya, 1425).

\section{Judicial Review Methods in Libyan Positive Law}

In Libyan positive law, judicial review differs by the type of appeal and its procedures. The methods of judicial review differ by the nature of judgment issued by the court and by case, in accordance with the provisions of Libyan criminal legislation. The methods of judicial review according to the type of judgment in Libyan criminal legislation will be discussed below.

\section{First: Review of Trial Judgments}

Trial judgment is issued by the Court of First Instance. It may be challenged by filing an appeal to the Court of Second Instance. Trial judgment can be issued in absentia or in person (Husni, 2019).

If the judgment is not pronounced in the presence of the defendant, the deadline for his objection begins from the day the pronouncement becomes known to the convicted person. Otherwise, objection is possible until the extinction of the case by prescription (Libyan Code of Criminal Procedures, Article: 361). Article 362 of the same Law states, "Objections by civil plaintiffs shall not be accepted" (Libya, n.d.).

Such objection is based on the principle that an individual shall not be held guilty unless the court has heard his defense. In absentia judgments are issued without the court hearing the defense of one of the litigants of the case. It is therefore a weak judgment and possibly incorrect, as it is not based on sufficient knowledge of the case elements. The law sees that such judgment has no enforcement power or power to end the case. Therefore, it allows objection so that the case can be presented anew before the court, which then hears the defense of the absent litigant and gather previously missing information to produce a sound judgment. After obtaining the full elements of the case, it then confirms or amends its judgment (Husni, 2019, 2: 1196-1197).

It bears mentioning that objection is a method of reviewing in absentia judgments in misdemeanor and infraction cases, regardless of whether such judgments are issued by the Court of First Instance or of Second Instance. The Libyan Code of Criminal Procedures states, "Judgments in absentia and the objection thereto before the Court of Appeal shall follow what has been decided before the Court of First Instance" (Libyan Code of Criminal Procedures, Article: 379). The Egyptian Court of Cassation also states, "Judgments in absentia and the objection thereto before the Court of Appeal shall follow what has been decided before the Courts of First Instance" (Egyptian Court of Cassation, 2001).

It is evident to the researcher from the above discussion that the Libyan legislator has made objection as one of the methods for the review of in absentia judgments in cases of misdemeanors and infractions, but not criminal offences. It aims (i) to protect the defendant's guarantees and right to defend himself and (ii) to provide the court with the opportunity to gather missing information so that it can produce a sound judgment based on complete evidence. 


\section{Second: Review of Final Judgment}

Final judgment is that which is not subject to appeal. A judgment becomes final if it is issued without opportunity for appeal, if its statutory limit is left to expire, or if it is appealed and then adjudicated by the Court of Appeal (Husni, 2019). The Libyan legislator allows final judgments to be reviewed by way of cassation appeal and rehearing. They are briefly explained as follows.

\section{Review of Final Judgments by Cassation}

Cassation is an extraordinary method to appeal against and review final judgments issued by a court of highest instance. Cassation appeal aims to examine the appealed judgment to verify its consistency with the law, whether in terms of the substantive rules that it applies, the procedures for its emergence, or the procedures on which it is based. In cassation appeal, the case is not re-presented to the judiciary because it has been presented before two levels of courts prior to its appeal. The case is presented to the Court of Cassation to be examined and reviewed independently of the facts of the case. The Court also evaluates the degree to which the judgment is consistent with the law (Muștafa, 1964).

The Supreme Court's (Court of Cassation) review of the final judgment by way of cassation appeal may lead to the rejection of the appeal; the Court's amendment of the error and adjudication according to the law; or the Court's remanding of the case to the issuing court to adjudicate the case anew. The Libyan Code of Criminal Procedures states, "If the appeal or its grounds are filed after the deadline or the grounds are inacceptable in their relation to the merits, the Court shall reject the appeal.

If the appeal is accepted and based on the first situation described in Article 381, the Court shall correct the judgment and adjudicate according to the law.

If it is based on the second situation described in the said Article, the Court shall reject the decision and remand the case to the issuing court-constituted of other judges-to be adjudicated anew. Nevertheless, it shall be possible to refer it to another court when necessary.

If the challenged judgment is issued by a Misdemeanor Court of Appeal or a Criminal Court on a misdemeanor or infraction that occurred during its session, the case shall be remanded to the competent Summary Court to decide thereon so it can examine the same according to customary norms" (Libya, n.d.).

\section{Review of Final Judgments by Rehearing}

Appeal by rehearing is an extraordinary method of challenging and reviewing a judgment. The law allows this method in limited cases to object final convictions in felonies and misdemeanors, so as to amend judicial errors related to the evaluation of the facts of the case (Husni, 2019). The Libyan legislator has specified cases that are subject to appeal by rehearing. Article 402 of the Libyan Code of Criminal Procedures states, "It shall be possible to request the rehearing of final judgments that impose sentences in cases of misdemeanors and infractions in the following circumstances:

a. If the defendant has been convicted of murder and the alleged victim is then found.

b. If a person has been convicted of a given incident, then another person is convicted of the same incident, and both convictions are contradictory such that they result in the exculpation of one of the convicted persons. 
c. If a witness or expert is convicted of a false testimony under the provisions of the Penal Code, or if he is convicted of falsifying a document submitted during the examination of the case, and the testimony, expert report, or document has had an effect on the judgment.

d. If the conviction is based on a judgment issued by the Civil Court or a Civil Status Court and that judgment has been overturned.

e. If facts occur or emerge after the judgment, or if documents that were not known during the trial are presented, and such facts or documents are to establish the innocence of the accused." (Libya, n.d.)

After the Court of Cassation reviews the judgment following the request for rehearing, it may overturn the judgment and acquit the defendant; refer the case to the issuing court to decide on the merits; and consider the merits of the case and only overturn of the judgment whatever it deems erroneous. The Libyan Code of Criminal Procedure states, "The Court of Cassation shall decide on the request after hearing the statements of the Public Prosecution and the litigants, and after doing what it deems necessary by itself or by whomever it delegates for the same. If it accepts the request, it shall overturn the judgment and acquit the defendant if his innocence is evident. Otherwise, it shall refer the case to the court which issued the sentence, provided it is constituted of other judges, to decide on the merits, unless it decides to do so by itself. However, if it is not possible to perform a re-examination, as in the case of the death or insanity of the convicted party or extinction of the penal case by prescription, the Court of Cassation shall examine the merits of the case and only overturn of the judgment whatever it deems erroneous." (Libya, n.d.)

\section{Third: Judicial Review to Correct Material Errors or Errors in the Law or Its Texts}

In addition to the cases that are subject to appeal and judicial review in Libyan criminal legislation, the Libyan legislator specifies two cases to amend errors emerging in judgments. Both are explained below.

\section{Judicial Review to Correct Material Errors}

Article $\mathbf{3 1 0}$ of the Libyan Code of Criminal Procedure states, "In the event of a material error in a judgment or an order by the investigating magistrate or the Indictment Chamber, and where the error does not lead to invalidation, the body which issued such judgment or order shall amend the error, either on its own accord or upon a motion by either one of the litigants, upon summoning the litigants to attend. The amendment is carried out in the discussion chamber after hearing the statements of the litigants, and it is indicated to on the margin of the judgment or order. The correction of the name and title of the defendant shall also follow this procedure" (Libya, n.d.)

Under this provision, the issuing court shall correct material defects and errors that do not result in invalidity, either on its own accord after summoning the litigants to attend and hearing their statements, or at the request of litigants-who can request for their amendment-to the entity that issued the erroneous procedure (al-Shawi, n.d.). The previously mentioned Article is not related to the correction of an invalid procedure specified by Article 308 of the Libyan Code of Criminal Procedure, "The judge may correct, even if on his own accord, any procedure that he deems to be invalid" (Libya, n.d.). 
2. Judicial Review to Correct Errors in the Law or Its Texts

The Libyan legislator grants the Court of Cassation the power to correct errors in the law or in the mentioning of its texts. In this case, the judgment cannot be overturned so long as the imposed sentence is prescribed in the law for the crime. The Court of Cassation shall correct the occurred judgment. Article 394 of the Libyan Code of Criminal Procedure states, "If the arguments of the judgment include an error in the law, or in the case of an error in the mentioning of its texts, the judgment may not be overturned if the imposed sentence is prescribed by law for the crime. The Court shall correct the error that occurred" (Libya, n.d.). Looking at the important role of the Court of Cassation in amending judgments, some jurists argue for the necessity to expand the power of the Court of Cassation to correct errors in the law and its texts, whereby the Court of Cassation is granted the power to reduce a sentence or decide to reject an appeal (al-Fakhiri, 2016).

\section{Conclusions and Recommendations}

1. The constitutional basis for judicial review is the constitutional recognition of the right to litigation and legal recourse, as well as the implementation of the two-level litigation principle. This is the approach taken by the Libyan Constitutional Declaration.

2. Evidence supporting judicial review in Islamic law is established in the Quran, Sunnah, and consensus. The justification for judicial review is the contravention of a judgment to the Quran, Sunnah, consensus, apparent analogy, or general principles, or the presence of an error and injustice in the judgment. In such cases, the judgment must be overturned.

3. The legitimacy of judicial review in Islamic law and positive law comes back to the fundamental reasons prohibiting crime.

4. The judicial review doctrine stems from the principle of two-level litigation, the latter of which is considered as the one of the most important principles of modern judicial systems. It guarantees the proper conduct of justice, as it encourages judges of courts of first instance to be diligent and careful with their judgments for concern that they may be annulled or amended by courts of second instance.

Based on the above conclusions, the researcher recommends the following:

1. The necessity to expand the field of judiciary in accordance with Islamic law in Arab countries, whose constitutions recognize Islamic law as a chief source of legislation.

2. The necessity to implement Islamic law in commercial conducts, as is already the case in theft, hirabah, and hudud and qișaș (retributive justice) offences.

3. Carrying out judicial reviews according to Islamic law, so that the matter of review is carried out by a scholarly judicial entity characterized by integrity, prudence, and proficiency.

4. Retaining the theory of justified punishment and expanding the power of the Court of Cassation to correct errors in the law or its texts, whereby the Court of Cassation is granted the power to reduce a sentence or decide to reject an appeal. jkujj 


\section{References}

Abu 'Amir, M. Z. (1997). 'Ilm al-ljram wa 'Ilm al-'Iqab. Alexandria: Dar al-Mațbu'at alJami'iyyah.

Al-Bayhaqi, A. H. (N.D). Al-Sunan al-Kubra. Beirut: Dar al-Ma'rifah.

Al-Bukhari, M. I. (2003). Șaḥih al-Bukhari. Beirut: Dar al-Kutub al-'Ilmiyyah.

al-Fakhiri, M. (2016). Athar al-Ṭa'n bi al-Naqụ fi al-Mawad al-Jina'iyyah. Benghazi. Libya: Dar al-Kutub al-Wațaniyyah.

Al-Fayruz A. M. Y. (1951). Al-Qamus al-Muhiț. Beirut: Mu'assasah al-Risalah.

Al-Ḥasan, I. M. (2001). 'Ilm al-ljram. Baghdad: Dar al-Ma'arif.

Al-Kasani, A. D. (1986). Bada'i' al-Șana'i' fi Tartib al-Shara'i'. Beirut: Dar al-Kitab al-'Arabi.

'Allam, M. Y. (2012). Mabda' al-Taqaḍi 'ala Darajatayn bayna al-Qawanin al-Waḍ 'iyyah wa alShari'ah al-Islamiyyah. Cairo: al-Markaz al-Qawmi li al-Ișdarat al-Qanuniyyah.

Al-Qurțubi, S. D. M. (N.D). Al-Jami' li Ahkam al-Qur'an. Beirut: Dar al-Fikr.

Al-Sarakhsi, M. A. (1993). Al-Mabsuț. Beirut: Dar al-Ma'rifah.

Al-Shafi i, M. I. (1990). Al-Umm. Beirut: Dar al-Ma'rifah.

Al-Shawi, T. (N.D). Majmu'ah Qanun al-ljra'at al-Jina'iyyah. Cairo: Dar al-Nashr li al-Jami'at al-Mișriyyah.

'Aymur, R. (2005). Mabda' Muraja'ah al-Ahkam al-Qaḍa'iyyah bayna al-Shari'ah al-Islamiyyah wa al- Nuẓum al-Waḍ 'iyyah (master's thesis). Batna, Algeria: Université Colonel Hadj Lakhdar.

Egyptian Court of Cassation. (2011). Ḥukm Maḥkamah al-Naqụ al-Mișriyyah fi al-Ṭa'n al-Jina'i. No: 6479.

Husni, M. N. (2019). Sharh Qanun al-ljra'at al-Jina'iyyah wifqan li Aḥdath al-Ta'dilat. Cairo: Dar al-Nahdah al-'Arabiyyah.

Ibn Farḥun, B. D. (2002). Tabșirah al-Ḥukkam fi Ușul al-Aqḍiyyah wa Manahij al-Aḥkam. Beirut: Dar al-Kutub al-'Ilmiyyah.

Ibn Ḥanbal, A. A. (1999). Musnad al-Imam Ahmad ibn Ḥanbal. Beirut: Mu'assasah al-Risalah. Ibn Mandhur, M. M. (1993). Lisan al-'Arab. Beirut: Dar lhya' al-Turath al-'Arabi.

Ibn Qayyim, M. (1991). I'lam al-Muwaqqi'in 'an Rabb al-'Alamin. Beirut: Dar al-Kutub al'Ilmiyyah.

'Ilish, M. (1989). Manḥ al-Jalil Sharḥ Mukhtașar Khalil. Beirut: Dar al-Fikr.

Jarjis, M. (1996). Mu'jam al-Mușțalaḥat al-Fiqhiyyah wa al-Qanuniyyah. Beirut: al-Sharikah al-'Alamiyyah li al-Kitab.

Mușțafa, M. (1964). Sharh Qanun al-ljra'at al-Jina'iyyah. Cairo: Dar wa Mațabi' al-Sha'b.

Qal'aji, M. R. (1984). Mu'jam Lughah al-Fuqaha'. Beirut: Dar al-Nafa'is.

'Umar, N. (N.D). Ușul al-Murafa'at al-Shar'iyyah wa 'Ilm al-Qaḍa' fi al-Mamlakah al-'Arabiyyah al-Su'udiyyah. Alexandria: Mansha'ah al-Ma'arif.

Wașil, N. F. (N.D). Al-Sulțah al-Qaḍa'iyyah wa Niẓam al-Qada' fi al-Islam. Cairo: al-Maktabah al-Tawfiqiyyah. 